\title{
Evolution of Concepts Related to the Term «Brand Reputation» and Their Relationship
}

\section{Evolución de los conceptos relacionados con el término «reputación de marca» y su relación}

\section{Kurbangalieva Dinara Lenarovna}

Graduate student, Department of General Management, Institute of management, economics and finance, Kazan (Volga Region) Federal University

ORCID: https://orcid.org/0000-0003-1302-9614

Received 09-08-20 Revised 10-10-20

* Correspondence

Email: dhasanova@list.ru
Accepted 20-12-21 On line 02-17-21

Citation:

Kurbangalieva Dinara Lenarovna. (2021). Evolution of Concepts Related to the Term «Brand Reputation» and Their Relationship. Propósitos y Representaciones, 9(SPE2), e1009. http://dx.doi.org/10.20511/pyr2021.v9nSPE2.1009 


\section{Summary}

Throughout the past decade, the theme of reputation has attracted growing interest in the world of corporate business. This interest is primarily due to the fact that reputation is beginning to have an increasing impact on the capitalization of brands. In addition, the accelerated development of information technology and the subsequent large-scale expansion of the organization into digital markets, with a new force, expanded the scientific field of research on the impact of intangible factors on the activities of brands. In numerous publications devoted to the study of the term reputation, both domestic and foreign researchers, there are different approaches to its definition. Previous analysis of works has shown that the reputation of an organization is often confused with the categories «brand», «brand image», «intangible assets», «goodwill» or «business reputation» (Malakhov, 2009), which have other nature and meaning. This article analyzes the views of various researchers of the above terms and, based on the work done, attempts to systematize these terms and offers the author's definition of the definition of «brand reputation». This research will provide a theoretical basis for further research, namely, quantitative assessment of reputation in the era of market transformation and the spread of modern technologies.

Keywords: reputation, brand, image, goodwill, corporate reputation, competitiveness

\section{Resumen}

A lo largo de la última década, el tema de la reputación ha atraído un interés creciente en el mundo de los negocios corporativos. Este interés se debe principalmente al hecho de que la reputación comienza a tener un impacto creciente en la capitalización de las marcas. Además, el desarrollo acelerado de la tecnología de la información y la posterior expansión a gran escala de la organización hacia los mercados digitales, con una nueva fuerza, expandieron el campo científico de investigación sobre el impacto de los factores intangibles en las actividades de las marcas. En numerosas publicaciones dedicadas al estudio del término reputación, tanto investigadores nacionales como extranjeros, existen diferentes enfoques para su definición. El análisis previo de trabajos ha demostrado que la reputación de una organización a menudo se confunde con las categorías «marca», «imagen de marca», «activos intangibles», «fondo de comercio» o «reputación empresarial» (Malakhov, 2009), que tienen otra naturaleza y significado. Este artículo analiza las opiniones de varios investigadores sobre los términos anteriores y, a partir del trabajo realizado, intenta sistematizar estos términos y ofrece la definición del autor de la definición de «reputación de marca». Esta investigación proporcionará una base teórica para futuras investigaciones, a saber, la evaluación cuantitativa de la reputación en la era de la transformación del mercado y la difusión de las tecnologías modernas.

Palabras clave: reputación, marca, imagen, fondo de comercio, reputación corporativa, competitividad

\section{Introduction}

The growing attention to intangible resources as a valuable instrument of the organization's competitive advantage over other entities in the industry is associated with the progressive development of the post-industrial society thanks to technology. Indeed, technologies are transforming reality, and the rules of behavior of market participants are changing along with it. Some researchers argue that most of the existing laws by which business strategy and economic theory of the twentieth century were built turned out to be a set of theories created on the basis of assumptions that became outdated as technology developed (Pansayuk, 2006). Often for a brand on a platform, the most important are resources that are not enclosed within the organization, but on the contrary - external ones, to which the category can be attributed as «the reputation of the organization». Based on the foregoing, there is a tendency of increased interest of researchers and business representatives to focus in their strategy on the creation and development of such a valuable intangible resource, which is outside the direct control of management and affects the results of operations, the company's capitalization and forms a sustainable competitive advantage, such as the reputation of the organization (Sharkov, 2006). 
However, to solve this problem, in this article we propose to focus on the formation of the theoretical basis for the representation of the term reputation. Thus, we can systematize similar terms such as «brand», «image», «intangible assets», «goodwill» and «delovaya reputation».

The emphasis on the resources of large organizations as a source of unique competitive advantages, better known as the resource-based approach, originated in the writings of E.Penrose (Prahlad \& Hamel, 1990), who emphasized that large organizations (corporations) have unique resources that are not quickly replicated for other organizations, providing it with a stable competitive advantage. Next, the teachings of E.Penrose (Prahlad \& Hamel, 1990) has been developed by such authors as J.Barney (Barney, 1991), B.Wernerfeldt (Wernerfelt, 1984), K. Prahalad and G. Hamel (Safiullin et al., 2019). According to their research, the organization should be considered as a set of tangible and intangible resources. New York University Professor B. Lev (Baruch Lev, 2000) emphasizes the increased role and importance of intangible resources as the main driving force of business value.

Despite the significant contribution of scientists of the last century to the theoretical issues of using objects that do not have a material form, the conceptual and terminological base of intangible objects remains debatable, namely, the erroneous identification, from our point of view, of the terms «intangible resources» and «intangible assets». The category of «intangible resources» is broader and this term includes everything that arises from production processes, systems, or organizational culture: people's knowledge and skills, norms and value systems, management system characteristics, databases and software, production experience, licenses, trade secrets, consumer relationships, reputation, and consumer emotional perception (Anokhina, 2015; Gordina, 2007). The term «intangible assets», in our opinion, is interpreted more narrowly than «intangible resources» and is used in accounting. In accounting terms, intangible assets are identifiable intangible assets, such as property rights to intellectual property or other similar rights, capable of generating income for a period exceeding one year (Ogilvi, 2003; Reva, 2018). In addition, the term «intangible assets» can often be found in marketing textbooks, where this category includes the brand, brand image, and reputation. For example, Professor and well-known practitioner in the field of corporate reputation G. Dowling (Elshina, 2009) notes that the share of intangible assets of well-known brands «dissolved reputation, image and brand».

In numerous publications devoted to the study of the term reputation of the organization, both domestic and foreign researchers find different, sometimes diametrically opposite approaches to its interpretation. This is due to the fact that reputation is a category that is used in various fields of activity: marketing, accounting, and sociology. At the same time, each discipline focuses on the key aspects of this phenomenon, thereby introducing certain content elements: image, brand and reputation - in marketing, goodwill or business reputation - in accounting, prestige - in sociology. Thus, the analysis of more than 30 definitions of «reputation of organizations» that currently exist in the scientific literature leads to the conclusion that it is necessary to systematize these elements.

\section{Methodology}

The theoretical and methodological basis of the article is the classical paradigms, fundamental provisions, concepts and approaches formulated by domestic and foreign authors dealing with the formation and assessment of reputation in various disciplines (marketing, finance and accounting, management, sociology). In this article, by analyzing and comparing different views on the definition of the terms «brand», «brand image» and «reputation», «goodwill», we will be able to identify the relationship between them and try to offer the author's definition of the term «brand reputation».

In this article the analysis will use the works of such foreign and domestic researchers, as D.Aaker (2003), E.Yohimsteiler (2003), D.Ogilvie (Penrose, 1995), Zh.-N.Kapferer (Keller, 2013), K. L. Keller (Kosykh, 2012), G.Dowling (Elshina, 2009), Ch.Fombrun and K.V.Riel (Gardner \& Levy, 1955), A.Topaliyan (Wernerfelt, 1984), M. Alvesson (Alvesson, 1990), V.N.Domnin (Domnin, 2006), O.A. Tretiak, S.A. Starov (Vazhenina, 2006), F.I. Sharkov (Smirnov, 2004), E.A. Smirnov (Sologubov, 2006), E.Yu.Salomatina and A.E.Ivanov (Shepel, 
2010), A.D.Krivonosov, O.G.Filatova and M.A.Shishkina (Kurbangaliyeva, 2019), A.Y.Panasyuk (POLOZhENIye PO BUKhGALTERSKOMU UChETU, 2010), I.Gordina (Kalinskiy et al., 2018), V. M. Shepel (Sokolov, 2005), D.V. Lugovsky and T.G. Belozerova (Belozerova \& Lugovskiy, 2009), Ya.V. Sokolov (Starov, 2008), V. E. Reva (Salomatina \& Ivanov, 2016), V. N. Kosykh (Krivonosov et al., 2008), E. Elshina (Ferris et al., 2003), I.S.Vazhenina, A.A. Akimov and others (Akimov \& Bredkhina, 2015).

\section{Results}

In the course of the analysis carried out in this article, we came to the conclusion that the marketing approach determines the use of terms similar in meaning to the organization's reputation as «brand» and «brand image» as synonyms, which, in our opinion, is not entirely justified. The analysis of the works shows that there are different points of view of scientists on when the mention of the brand first appeared: some authors (Domnin, 2006; Vazhenina, 2006) attribute the emergence of the term «brand» to the early 30s. last century, others (Topalian, 1984), distinguishes an earlier period, the end of the XIX century. and is associated with the emergence of the still wellknown brands Procter \& Gamble (1837), Sberbank (1847), Coca - Cola (1886), American Express (1850). The company's brand set them apart from their competitors and created a reputation as a supplier of high-end products, thereby increasing the company's value. In other words, if customers can find that a product has a unique feature that sets it apart from others, and it can be described, then it is a brand. We share this opinion and highlight functional advantages as the Foundation that forms the organization's brand.

D. Aaker (2003) made a significant contribution to the development of the «brand» concept by offering his own understanding of the «brand» category. According to the researcher, «a brand is a name, term, sign, symbol, picture or their combination, designed to identify the goods and services of a manufacturer or a group of sellers and differentiate them from those of competitors». At the same time, D. Aaker recommended choosing one of four aspects when implementing measures to develop a brand: brand as a product, as an org anization, as an individual or as a symbol.

One of the terms that are close to and out of the brand category is «brand image». The term «brand image» was first used by B. Gardner and S. Levy in the article «Product and brand» (Gileva, 2008) published in 1955 in the Harvard Business Review. The authors believed that the important thing is not the brand as it was developed by marketers, but the brand image: how distinct and attractive it is perceived by consumers. In other words, the brand image is understood as its integral image, which represents a set of associations formed by the consumer at the points of contact with the brand.

A similar opinion about the relationship between a brand and a brand image is held by domestic researchers, for example, A.D. Krivonosov and co-authors, who define a brand as «a set of consumer perceptions of a brand that includes a set of stereotypes, symbols and emotional sensations» (Kurbangaliyeva, 2019). This idea is taken up by A.Y.Panasyuk, who believes that the image is «purposefully formed, designed to have an emotional and psychological impact on someone» (POLOZhENIye PO BUKhGALTERSKOMU UChETU, 2010). Image, as defined by I.Gordina, is an image of the company created by external audiences, its emotional perception outside (Kalinskiy et al., 2018). V. M. Shepel emphasizes the role of communication and specifies that the image is created «by the media, a social group, or by the individual's own efforts in order to attract attention» (Sokolov, 2005).

Continuing the systematization of terms, we note that we share the views of Ch.Fombrun and K.V.Riel (Gardner \& Levy, 1955), whom defines the relationship between reputation and brand image as follows: the path to establishing a positive reputation lies through the creation of a favorable brand image, which should then be associated with several values that are important for consumers, external agents. An organization cannot change their values, but it can affect their perceived perception and sometimes the emotional attitude they have towards it. G. Dowling adheres to a similar opinion and notes that let the establishment of reputation go through the 
creation of a favorable image (Elshina, 2009). We share the opinion of the authors, however, in addition to the brand image, we believe that functional benefits are also an integral part of the organization's brand.

Based on the above, we will try to systematize the described approaches and present the relationships between the analyzed concepts of brand, brand image and brand reputation for line companies in Fig. 1.

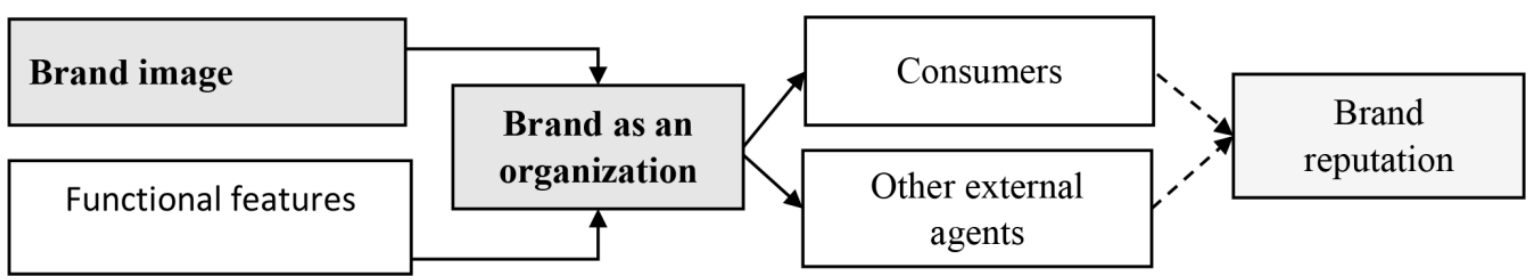

Figure 1. Relationship between brand, brand image, and brand reputation (compiled by the author)

Analysis of approaches to the definition of the term «reputation» in accounting indicates that researchers also use the terms «business reputation» or «goodwill», respectively, to describe similar processes (Kapferer, 2006). In Russia, experts in the field of accounting D.V. Lugovsky and T.G. Belozerova (Belozerova \& Lugovskiy, 2009) explain the simultaneous use of two terms by the attitude to borrowing in Russian. Professor Ya.V. Sokolov (Starov, 2008) supports the idea of the previous author and adds that supporters of borrowing, given the novelty of this concept and the absence of analogues in Russian, introduced the term «goodwill». Their opponents, on the other hand, exclusively use the Russian equivalent of the term «business reputation».

One of the first researchers who defined reputation as an independent definition in 1984, A. Topaliyan (Wernerfelt, 1984) understands corporate reputation as the expectations, views and feelings of consumers about the essence of a company based on its corporate identity. His point of view is shared by G. Dowling and adds that in addition to the result of interaction, feelings and opinions of a person about a company, reputation is a set of meanings for which a company is known, and with which people describe, remember and relate to it (Elshina, 2009). In turn, Ch. Fombrun emphasizes the subjective essence of reputation: in his opinion, corporate reputation is a «pure» emotional reaction - good, bad, weak or strong to the name of the company (Gardner \& Levy, 1955). Whereas previous authors emphasized the perception or opinion of the consumer about the company, M. Alvesson (Alvesson, 1990) focuses on key aspects like «society» and «like-minded people»: reputation refers to a holistic and vivid impression held by a certain group of like-minded people, partly as a result of processing information carried out by members of the group.

Among domestic researchers, we highlight the work of I. S. Vazhenina, which defines reputation as an objectively formed set of opinions about the company of all agents who interact with it to some extent. V. E. Reva describes reputation as a set of assessments about the advantages and disadvantages that The company is associated with in the eyes of contractors, consumers and the client (Salomatina \& Ivanov, 2016). To previous developments of the reputation theory, V. N. Kosykh adds that reputation is a forecast of the company's behavior by the target audience based on available information, experience and impressions (Krivonosov et al., 2008). E. Elshina (Ferris et al., 2003) notes the duration of the period during which the public assessment, that is, reputation, is formed.

From the point of view of sociology, foreign researchers consider reputation as a social phenomenon and a feature of modern society, as well as a mechanism of social control and a source of missing information (Fombrun, 2007), which allows building broader and more dynamic networks, developing communities, and interacting both within one's own and with other social groups (Conte et al., 2008). F. V. Malakhov, in the framework of his dissertation research, (Mikhaylova, 2011) notes that the reputation of an organization is an impersonal collective view of 
the past actions and results of the company's work, based on the assessment of the organization's social activities among representatives of groups interested in its work.

A review of different views of researchers on the concept of «reputation of organizations» allows us to conclude that depending on the discipline that contributes its key accents to the definition of the term reputation, there are also different interpretations of the term «reputation». This fact allows us to identify the most common elements that are key to understanding the essence of an economic entity's reputation: goodwillldelovaya reputation, emotional perception or brand image (includes such properties as impressions, feelings or opinions), evaluation depending on the experience of interacting with the brand, functional qualities, signalslinformation (leveling information asymmetry), intangible asset, competitive advantage, intangible resource, a group of like-minded people or a community, not subject to control, reliable cost estimation and reflection on the balance sheet. in table 1 .

We will highlight the key aspects that make up the reputation of the brand (organization)

Table 1. Key characteristics of brand reputation from the point of view of foreign and domestic researchers (compiled by the author)

\begin{tabular}{|c|c|c|c|c|c|c|c|c|c|c|c|}
\hline Author \Source & 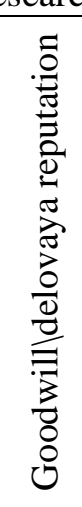 & 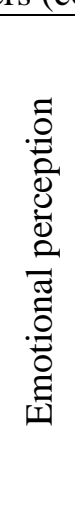 & 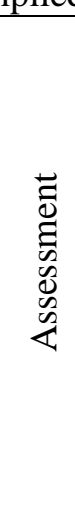 & 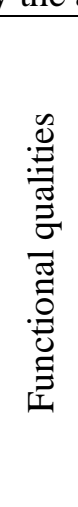 & 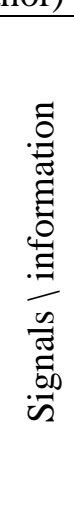 & 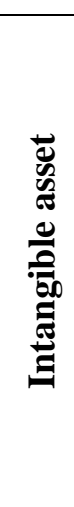 & 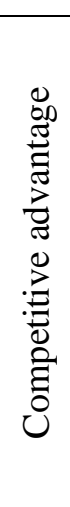 & 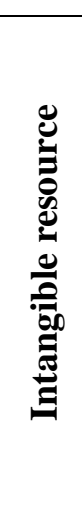 & 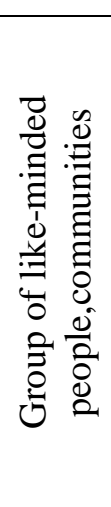 & & 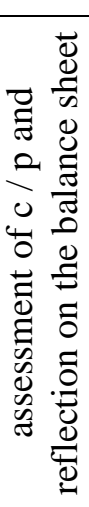 \\
\hline F.V. Malakhov (2011) & & & + & & & & & & + & & \\
\hline R. Conte (2008) & & & + & & & & & & + & & \\
\hline J.R. Ferris (2007) & & & + & & + & & & & + & & \\
\hline $\begin{array}{l}\text { F.Pikseley , I.F. Shera and } \\
\text { others (Kapferer, 2006) }\end{array}$ & + & & & & & + & & & & & \\
\hline $\begin{array}{l}\text { A.A. Akimov and others } \\
(2015) \text {. }\end{array}$ & + & & & & & + & & & & & \\
\hline M.Alvesson (1990) & & & & & + & + & & & + & & \\
\hline G. Dowling (Elshina, 2009) & & + & + & + & & + & & & & & \\
\hline $\begin{array}{l}\text { Ch. Fombrun, K.V.Riel } \\
\text { (Gardner \& Levy, 1955) }\end{array}$ & & + & + & & + & + & & & & & \\
\hline $\begin{array}{l}\text { A.Topaliyan (Wernerfelt, } \\
\text { 1984) }\end{array}$ & & + & & + & & + & & & & & \\
\hline I. S. Vazhenina & & & + & & & & + & + & & & \\
\hline $\begin{array}{l}\text { V.E. Reva (Salomatina \& } \\
\text { Ivanov, 2016) }\end{array}$ & & & + & & & + & & & & & \\
\hline $\begin{array}{l}\text { V. N. Kosykh (Krivonosov et } \\
\text { al., 2008) }\end{array}$ & & + & + & & & & & & & & \\
\hline E. Elshina (Ferris et al., 2003) & & & + & & & & & & + & & \\
\hline $\begin{array}{l}\text { IFRS (Ogilvi, 2003) and PBU } \\
\text { (Reva, 2018) }\end{array}$ & + & & & & & & & + & & + & + \\
\hline Author's suggestion & & & + & & & & + & + & + & + & + \\
\hline
\end{tabular}

\section{Discussions}


Based on the results of the analysis in this article, we propose to adhere to the classical approach to understanding the «brand» (Aaker \& Yokhimshtayler, 2003), focused on the organization. A brand as an organization distinguishes from applicants for this title a long stay in the market, the quality and stability of products that meet the brand's promises, and consumer loyalty (the number of potential consumers who are aware of the brand and the number of regular customers who can name the distinguishing features of the brand's products). In addition, it was concluded that brands create an image or brand image in the minds of observers by combining verbal, visual and emotional signals that encourage consumers to identify with the brand. Also, in the course of analyzing the term goodwill or business reputation, we came to the conclusion that due to the similarity of the definition, namely the excess of the market value over the company's book value, many researchers perceive the reputation of an organization and goodwill as identical concepts. We do not agree with this approach, since it limits the scope of research in accounting and bookkeeping and requires compliance with a certain criterion. Also, in the course of working on the article, we came to the conclusion that «goodwill» and «delovaya reputation» can be interpreted as synonyms, depending on the method of reflection on the balance sheet. It should be noted that reflection on the balance sheet is strictly regulated by two regulatory documents: IFRS 38 «Intangible Assets» (Ogilvi, 2003) («goodwill») and GAAP 14/2007 «Accounting for Intangible Assets» (Reva, 2018) («delovaya reputation »). It should be noted that in the domestic literature, research on the category «delovaya reputation» has become widespread in the works.

Thus, the analysis of the key aspects that form the term brand reputation as an organization, as well as the concepts-categorical apparatus of the terms «brand reputation as an organization», «brand image», «goodwill or delovaya reputation» allow us to draw the following conclusions. First, reputation is formed by combining functional qualities and a favorable brand image, which must then be associated with several values that are important to consumers and external agents. Secondly, the terms «goodwill» and «delovaya reputation» should be used synonymously, but not identified with the concept of «brand reputation», since they are limited to the scope of accounting statements and require compliance with a certain criterion. Third, from the point of view of the interpretation of researchers who link reputation with the emergence of marketing as a discipline, the assessment of brand reputation is qualitative or subjective.

After analyzing the study's authors and the evolution of the most important terms come to the conclusion that the reputation of the brand is a special intangible brand assets, which is outside the direct control of the organization and should not be reflected on the balance sheet, but it contributes to the development and implementation of the strategy provides a sustainable competitive advantage is formed by the interaction of consumers and associates with the brand. At the same time, we mean the fact that the brand has been on the market for a long time, the quality and stability of its products, and customer loyalty.

The work done in this article allows us to identify the thesis that brand reputation belongs to the category of intangible resources, which will allow us to continue studying the term «brand reputation» from the point of view of innovations made by technologies, namely the spread of the Internet and the appearance of smartphones (Kurbangaliyeva, 2019). Based on the analysis carried out in the article, we can assume that the Internet provides a scientific field for quantifying the brand's reputation, taking into account the characteristics highlighted in the article.

\section{Conclusion}

We hope that this article can become the basis for further theoretical work of researchers interested in the formation and evaluation of brand reputation, and in general, changes made in the relationship between economic agents and technologies. These changes have led to the fact that the consumer's choice is no longer defined and is not limited to the offers of retail outlets, and the movement of information has ceased to be one-sided. These seemingly simple changes have a serious impact on the brand's performance, as the usual relationship between the brand, consumers, and other external agents has changed. Accordingly, the system of forming and evaluating the organization's reputation has changed. 


\section{Acknowledgments}

Acknowledgments: The reported study was funded by RFBR, project number 20-310-90042

Funding: The reported study was funded by RFBR, project number 20-310-90042

\section{References}

Aaker, D. (2003). Sozdaniye silnykh brendov. M.: Izdat.dom.Grebennikova.

Aaker, D., \& Yokhimshtayler, E. (2003). Brend liderstvo: novaya kontseptsiya brendinga. M.: Izdat.dom.Grebennikova.

Akimov, A.A., \& Bredkhina, K.V. (2015). Gudvill v finansovoy otchetnosti: sravnitelnaya kharakteristika trebovaniy rossiyskikh standartov bukhgalterskogo ucheta i mezhdunarodnykh standartov finansovoy otchetnosti. Vestnik Penzenskogo gosudarstvennogo universiteta, 3(11), 34- 36 .

Alvesson, M. (1990). Organization: from substance to image?. Organization Studies, 11(3), 373394.

Anokhina, E.A. (2015). Otsenka effektivnosti ispolzovaniya nematerialnykh resursov pri pomoshchi teorii nechetkikh mnozhestv. Vestnik BGU. Seriya 3. Gistoryya. Ekanomika. Prava, 3, 59-66. - ISSN 2308-9172

Barney, J. (1991). Firm resources and sustained competitive advantage. Journal of Management, $17(1), 99-120$.

Baruch Lev. (2000). Intangibles: Management, Measurement, and Reporting. Brookings institution press, Washington, D.C.,-- p.301.

Belozerova, T.G., \& Lugovskiy, D.V. (2009). Delovaya reputatsiya:slozhnost identifikatsii.yu otsenki i otrazheniya v uchete i otchetnosti. Vse dlya bukhgaltera, 11(239), 5-13.

Conte, R., Paolucci, M., \& Sabater - Mir, J. (2008). Reputation of innovating social networks. Advances in Complex Systems, 2, 255-270.

Domnin, V.N. (2006). Semanticheskiy kod Brenda. Brend-menedzhment, 4(29), 246-255.

Dowling, G. (2003). Reputatsiya firmy. Sozdaniye. upravleniye i otsenka effektivnosti. Izd. M.: Konsaltingovaya gruppa «Imidzh-Kontakt»: INFRA -M- $368 \mathrm{~s}$.

Elshina, E. (2009). Imidzh i reputatsiya: v chem otlichiya?. Moy profsoyuz, 38.

Ferris, G.R., Blass, R., Douglass, C., Kolodinsky, R.W., \& Treadway, D.C. (2003). Personal Reputation in Organizations. J.Greenberg (ed.) Organizational Behavior: The state of the Science. - USA: Lawrence Erlbaum Associates, Incorporated, 211-246.

Fombrun, C.J. (2007). Riel Essentials of Corporate Communication. Charles Fombrun и Kees van Reel — London: Routledge Taylor \& Francis Group, 306 p.

Gardner, B.G., \& Levy, S.J. (1955). The Product and the Brand. Harvard Business Review, 33-39.

Gileva, T.A. (2008). Osnovy kompetentnostno-oriyentirovannogo upravleniya nematerialnymi resursami predpriyatiya. Izvestiya irkutskoy gosudarstvennoy ekonomicheskoy akademii. Izd-vo: Baykalskiy gosudarstvennyy universitet (Irkutsk), 5, 70-75. - ISSN: 1993-3541.

Gordina, I.I. (2007). Imidzh organizatsii kak obyekt upravleniya. Laboratoriya reklamy. marketinga i PR, 1(50), 20-22.

Kalinskiy, O.I., Markov, S.V., \& Mikhaylova, O.Yu. (2018). Kompleksnoye upravleniye reputatsiyey predpriyatiy chernoy metallurgii na osnove metodov kolichestvennoy i kachestvennoy otsenki: Monografiya. - M.: Izd.Dom NITU «MISiS», - $492 \mathrm{~s}$.

Kapferer, Zh.-N. (2006). Brend navsegda: sozdaniye. razvitiye. podderzhka tsennosti Brenda. M.: Vershina.

Keller, K.L. (2013). Strategic Brand Management: Building, Measuring, and Managing Brand Equity. 4thed. Boston: Pearson Education Limited.

Kosykh, V.N. (2012). Upravleniye reputatsiyey: zachem i kogda reputatsiya nuzhna v biznese. $i$ reklama $v$ izmenyayushchemsya mire: regionalnyy aspect, 10, 104-114.

Krivonosov, A.D., Filatova, O.G., \& Shishkina, M.A. (2008). Osnovy piarologii. - SPb.: Roza mira. - S. 321.

Kurbangaliyeva, D.L. (2019). Reputatsiya v seti internet: otsenka vliyaniya na uroven prodazh predpriyatiya (na primere avtomobilnoy otrasli ekonomiki). Kazanskiy ekonomicheskiy vestnik, 1, 139-143. -. 
Kurbangaliyeva, D.L. (2019). Sravnitelnaya kharakteristika terminov «imidzh». «brend» i «delovaya reputatsiya» v teorii reputatsionnoy ekonomiki. Elektronnyy ekonomicheskiy vestnik tatarstana. Izdatelstvo: TsPEI AN RT (Kazan), 4, 44-51 eISSN: 2224-8331.

Malakhov, F.V. (2009). Upravleniye protsessom formirovaniya i razvitiya reputatsii sovremennoy rossiyskoy organizatsii Avtoreferat dis. Kand.sotsiol.nauk Moskva.

Mezhdunarodnyy standart finansovoy otchetnosti (IAS) 38 «Nematerialnyye aktivy».

Mikhaylova, N.V. (2011). Delovaya reputatsiya kak element stoimosti predpriyatiya. Belgorodskiy ekonomicheskiy vestnik, 4, 40-48.

Ogilvi, D. (2003). Ogilvi o reklame. - M.: Izdatelstvo Eksmo.

Pansayuk, A.Yu. (2006). Formirovaniye imidzha: strategiya. psikhotekhnologii. psikhotekhnika Izd. Omega -L. str.266.

Penrose, E. (1995). The theory of growth of the firm. University Press, Oxford.

POLOZhENIye PO BUKhGALTERSKOMU UChETU (2010). UChET NEMATERIALNYKh AKTIVOV (PBU 14/2007) (utverzhdeno prikazom Minfina Rossii ot 27.12.2007 № 153n. $\mathrm{s}$ izmeneniyami ot 25.10.2010 № 132n. ot 24.12.2010 № 186n).

Prahlad, C.K., \& Hamel, G. (1990). The core competence of the corporation. Harvard Business review, 68(3), 79-91.

Reva, V.E. (2018). Upravleniye reputatsiyey. Uchebnoye posobiye. - Izd. Izdatelsko-torgovaya korporatsiya «Dashkov i K» (Moskva). str. 136.

Safiullin, M.R., Elshin, L.A., \& Kurbangalieva, D.L. (2019). How does reputation economy engagement work to develop financial and economic activity?. Opción, Oficina de Publicaciones Científicas de la Facultad Experimental de Ciencias, Universidad del Zulia. Maracaibo - Venezuela, 23(35), 376-392.

Salomatina, E.Yu., \& Ivanov, A.E. (2016). Klassifikatsiya metodov ekonomicheskoy otsenki. Vestnik Yuzhno-Uralskogo gosudarstvennogo universiteta. Seriya Ekonomika $i$ menedzhment, 3, 26-36.

Sharkov, F.I. (2006). Magiya brenda: Brending kak marketingovaya kommunikatsiya. M.:AlfaPress.

Shepel, V.M. (2010). Imidzh - pokazatel kultury i kompetentnosti. Reputatsiologiya Izd. Redaktsiya zhurnala «Ekonomika i predprinimatelstvo» (Moskva) nomer, 1(5), 5-17.

Smirnov, E.A. (2004). Strategicheskiy menedzhment. oriyentirovannyy na brend. M.:Feniks. Natsionalnyy institut biznesa.

Sokolov, Ya.V. (2005). Gudvill - bolshaya novost. Bukh, 1(7).

Sologubov, S.N. (2006). Postroyeniye i razvitiye brendov tovarov massovogo potrebleniya: dne. ... kand. ekonom. nauk. - Volgograd: GOU VPO «Volgogr. gos. tekhn. uni-t», $157 \mathrm{~s}$.

Starov, S.A. (2008). Upravleniye brendami: uchebnik. SPB.: Izd-vo «Vysshaya shkola menedzhmenta».

Topalian, A. (1984). Corporate identity: beyond the visual overstatements. International Journal of Advertising, 3(1), 55-62.

Tretiak, O.A. (2001). Brend-kapital: soderzhaniye. denezhnaya otsenka i upravleniye. Brendmenedzhment, 2, 2-11.

Vazhenina, I.S. (2006). Delovaya reputatsiya kak konkurentnyy resurs kompanii. Zhurnal ekonomicheskoy teorii. - Izd. Institut ekonomiki Uralskogo otdeleniya RAN (Ekaterinburg), 4, 134-150.

Wernerfelt, B. (1984). The resourced-based view of the firm. Strategic Management Journal, 5(2), 171-180. 